\title{
Financial Risk Ratios and Earnings Management: Reducing Uncertainties in Shariah-compliant Companies
}

\author{
Soheil Kazemian (Corresponding author) \\ Accounting Research Institute, Universiti Teknologi MARA, Shah Alam, Malaysia \\ Tel: +603 55444914 Email: soheilkazemian@salam.uitm.edu.my \\ Siti Mazidah Hanif \\ Faculty of Accountancy, Universiti Teknologi MARA, Shah Alam, Malaysia \\ Tel: +601 48202562 Email: mazidahhanif@gmail.com \\ Zuraidah Mohd Sanusi \\ Accounting Research Institute, Universiti Teknologi MARA, Shah Alam, Malaysia \\ Tel: +603 55437910 Email: zuraidahms@salam.uitm.edu.my \\ Mohd Hassan Che Haat \\ School of Maritime Business and Management, Universiti Malaysia Terengganu \\ Tel: +6096683524 Email: hassan@umt.edu.my
}

\begin{abstract}
This study examines whether Shariah-compliant companies practice earnings management by investigating the relationship among the risk of financial distress, leverage, and free cash flow in discretionary accruals, which function as a substitute for earnings management. This empirical research is conducted on a sample of Malaysian Shariah-compliant companies from all industries in Bursa Malaysia from 2012 to 2014. Results show that Shariah-compliant companies are highly influenced by the risk of financial distress, leverage, and free cash flow. This study argues that working as either Shariah-compliant or non-Shariah-compliant does not affect the level of earnings management through financial distress, high leverage, and free cash flow by managers. Results should be of interest to stakeholders, shareholders, and regulatory bodies (i.e., the Shariah Advisory Council and the Securities Commission) that oversee the accountability of corporate financial reporting to prevent earnings management in Shariah-compliant companies. Findings can also aid relevant authorities (i.e., the Shariah Advisory Council and the Security Commission)
\end{abstract}

in Malaysia in overcoming or reducing problems related to earnings management. This study is one of the most significant works in Malaysia in terms of sample size and methodology. It argues that the three elements of earnings management (i.e., financial distress, high leverage, and free cash flow) influence better disclosure of reported earnings.

Keywords: Earnings management, Free cash flow, Financial distress, Shariah-compliant companies, Malaysia

\section{Introduction}

Islamic scholars issue various rulings that make Shariah principles compatible with the current business needs. Therefore, Shariah principles become a common condition in business transactions because they provide an overview and appreciation of full compliance with Islamic law (Falaika, 2002). Companies classified as Shariah-compliant are perceived as free from earnings manipulation, unethical transactions, and matters that have adverse effects on their investment activities. Engagement in these activities constitutes earnings manipulation 
(Mohamed Adil \& Mohd-Sanusi, 2013; Wan Ismail, Kamarudin, \& Sarman, 2015).

Earnings manipulation is a common practice among companies and is a result of serious agency problems (Darus, Amran, Nejati, \& Yusoff, 2014; Farooq, AbdelBari, \& Haniffa, 2015; Healy \& Wahlen, 1999). Earnings management may involve the manipulation of accounting records, intentional omission, or intentional misapplication of accounting principles. It is practiced by the management and often results in inaccurate and misleading financial reports (Aini, Takiah, Hamid, \& Jenny, 2006). Earnings management is related to low financial reporting quality (i.e., intentional misstatement or omission of amounts) or disclosures in financial statements to deceive financial statement users (MIA, 2002).

The main question on this matter is whether Malaysian Shariah-compliant firms differ from other firms in the quality of data disclosure. This study investigates whether the management of Shariah-compliant firms is more truthful than that of non-Shariah-compliant organizations in terms of managing earnings. Answers to these questions are important for investors who consider stock market transactions as un-Islamic and as a cover for speculative activities (Elgari, 1993; Shafiai \& Moi, 2015). These investors confuse risk with gharar and gambling, and thus shy away from investing in stock markets. Firms should take certain credible actions (i.e., compliance with Shariah/Islamic beliefs) to attract such reluctant investors (Alam, Hassan, \& Said, 2015; Bakar \& Ali, 2014). These actions can alter the perceptions of these reluctant investors regarding stock market investment.

The present study investigates the relationships among risk of financial distress (z-score), leverage, and free cash flows in earnings management in Shariah-compliant companies to address the issues of earnings manipulation in Shariah-compliant companies. Current studies on the effect of earnings management on report credibility are limited. These studies are in accordance with the criteria outlined by relevant parties, such as the Securities Commission, when selecting Shariah-compliant companies. The present research is particularly relevant for Malaysia to become the main center for Islamic international capital market. The Securities Commission fully understands the issues relevant to earnings management practice, particularly for companies that apply as Shariah-compliant.

The remainder of the study is structured as follows: Section two briefly discusses the previous literature and the current study's hypothesis development. Section three summarizes the methodology and data used in this study. Section four discusses the findings. Section five concludes.

\section{Literature Review}

\section{Shariah Capital Market}

Islamic businesses are currently gaining worldwide acceptance. About 50 countries, or one-fifth of the entire world population, are engaged in Islamic businesses at both domestic and international levels (Alam et al., 2015). Yousef (2001) stated that adopting moderate Islamic work ethics and satisfying all parties throughout the conduct of business should be the common goal.

Any instruction related to the Islamic market (i.e., operations and services) must comply with Shariah, which is the code of practice, principles, and rules of Islam (IOSCO, 2004). Islamic business laws are prepared with proper guidelines and various influences for the development of the Islamic business world. Al-Quran has long-stated concerns about the interest (riba) to protect businesspersons or any party involved. Another type of prohibited business is one that involves speculation (gharar). The prohibition of gharar is stipulated in the recorded authentic chain of narrations from the prophet (peace be upon him) and in Islamic transactions. Therefore, the difference 
between conventional and Islamic businesses is revealed.

Chapra and Chapra (1992) argued that Islamic scholars have a consensus that riba and gharar are part of unfair business practices, because a party stands to gain from the premeditated and calculated loss of another party. Shariah protects businesses and investors, consumers and producers, and the community and the nation from any deceitful and treacherous business dealings. However, many companies are entrapped in such activities whether they deliberately contribute to wealth or not (Nadzri \& Aida, 2009).

Business developments around the world have improved with the availability of Shariahcompliant securities presumably because of the increasing sense of responsibility and caution by the management and the increasing religious enthusiasm of the investors. Positive developments can be explained further by the argument that the basis for civilized behavior can affect changes in accountability and morality (Al-Shammari, 2013; Durant, 1950; Schelling, 1968). Shariah has set the proper and appropriate behavioral code of conduct for Muslims, including accountability in business dealings and transactions.

All resources belong to Allah, and people are responsible for their usage and consumption of these resources so that they can perform their duties to Allah in this world (Sulaiman, 2003). This statement can be applied to the interpretation of accountability, which is associated with the concept of financial reporting responsibility of management. The management of a company is mainly focused on wealth maximization through profit generation and is responsible only for reporting to shareholders the activities undertaken by the company. However, Muslims perceive that people have the greatest obligations and conscious responsibility to Allah, the Judge, followed by other parties according to their importance to a respective company. From the Islamic perspective, accountability leads to a sound economy, healthy politics, and religious uprightness, and thus it nurtures a God-fearing (taqwa) society. Shariah explicitly describes the guidelines of a legal system that clearly draws the line between truth and falsehood (baatil). Moreover, Islamic investors only invest if they believe that the investments do not conflict with Shariah (Derigs \& Marzban, 2008).

The Securities Commission of Malaysia is a corporate body that analyzes a company's information with reference to survey responses and the company's financial reports, as well as inquires about the company's management. The Shariah Advisory Council advises the Securities Commission on all matters related to the comprehensive development of the Islamic capital market and functions as a reference center for Islamic capital market-related issues. Members of the Shariah Advisory Council consist of Islamic scholars or jurists and Islamic financial experts.

Securities must first follow the process based on fundamental criteria compliant with Shariah principles in terms of business and investment activities to determine Shariah status before the securities can be listed as Shariah-compliant. The number of Shariah-compliant companies listed in Bursa Malaysia has increased rapidly. As of 2014 , about $89 \%$ of the companies listed in Bursa Malaysia were Shariah-compliant (Bursa Malaysia Securities Berhad, 2009).

\section{Earnings Management}

Healy and Wahlen (1999) and Abdul Rahman et al. (2016), found that earnings management occurs when managers choose the reporting methods and estimations that do not accurately reflect the economic status of their firms. Leuz, Nanda, and Wysocki (2003) defined earnings management as reported alterations in economic performance by insiders to either mislead the stakeholders or influence contractual outcomes. Sun and Rath (2008) identified earnings management as the exercise of judgment by managers to conceal true performance to 
influence stock performance, benefit from contractual terms between firms and managers, and control regulations or influence decisions.

Numerous studies have defined earnings management as various methods and concepts made by a company's management to compose information in the company's financial reports. Several factors that explain the attempts of managers to manage earnings have been discovered. Healy and Wahlen (1999), found that companies manage earnings to ensure that financial statements are seen as good before offering the securities to the public. This process is also referred to as "window dressing." The practice of earnings management also enhances a corporate manager's compensation and job security, prevents violations of the contract for a loan, reduces regulatory costs, and enhances the benefits to any regulations related to the company's business (Kazemian \& Sanusi, 2015).

Discretionary accrual (i.e., abnormal accrual) is a method used by most researchers to detect earnings management. Healy (1985), Said (2010), and Wan Ismail et al. (2015) are examples of previous researchers who utilized discretionary accruals to detect earnings management. Other researchers have developed several alternative models on an accrual basis to detect earnings management (i.e., investors' information on their properties). Therefore, total accruals are the priority in the measurement of discretionary accruals (Dechow, Sloan, \& Sweeney, 1995). Total accruals are divided into discretionary and non-discretionary components.

A simple model for researchers and any party involves the measurement of discretionary accruals as total accruals. Moreover, more sophisticated and current models are introduced to separate total accruals into discretionary and non-discretionary components (Dechow et al., 1995).

The discretionary allocation approach is a new model for detecting discretionary accruals. This model was proposed by Kothari, Leone, and Wasley (2005) after they innovated Jones' model by adding the performance factor. Kothari et al. (2005) suggested measuring discretionary accruals, which match the performance on return on assets (ROA), to control the effects of each organization's performance. After obtaining the results, performance that matches discretionary accruals was used to increase the reliability of research conclusions in revenue management. The results show no significant difference in the revenue management performance; thus, the company had not been engaged in earnings management.

\section{Shariah-compliant Criteria}

The utilized screening criteria examine the activities of a company to ensure that they follow the Shariah. Scrutinized and monitored companies that do not contradict the Shariah on the basis of certain conditions previously established and stated in the criteria set are classified as Shariah-compliant. Companies that do not comply with the Shariah are classified as non-Shariah compliant. These companies may be engaged in activities such as gambling and gaming, unlawful sale, conventional insurance, non-Shariah-compliant entertainment activities, usurious financial services, and other activities that are not in accordance with the Shariah (Securities Commission, 2011).

Abdul Rahman, Azlan Yahya, and Herry Mohd Nasir (2010) research was related to the screening process of Shariah-compliant securities. They discovered a method to calculate the difference in the analysis by comparing the Islamic Shariah Index of the Kuala Lumpur Stock Exchange with the Dow Jones Islamic Market Index when examining a company under Shariah-compliant criteria for investment purposes. However, the Kuala Lumpur Shariah Stock Index does not use the same methods and criteria used by the Dow Jones Islamic Market Index during the screening process. Three additional financial characteristics were observed from the Dow Jones Islamic Market Index compared with the 
Kuala Lumpur Shariah Stock Index (Hassan, Yusoff, \& Yatim, 2012). These characteristics include levels of debt, liquidity, and interest income, which are predetermined as the criteria that companies must observe during the screening process to be included under Shariah-listed companies. A sample test that uses the criteria set of the Dow Jones Islamic Market Index for Shariah-compliant companies in Malaysia shows a high reliance on debt to finance their capital.

On the basis of the list of Shariah-compliant companies, several researchers have studied the performance of the plantation industry in Malaysia. Dali Nuradli Ridzwan Shah Bin, Hamdi Hakeim, and Hamid Suhaila (2008) used multiple discriminant analyses and multiple regressions to identify companies that use financial ratios. They concluded that the acquisition credit/days and inventory turnover ratio can be used to distinguish Shariahcompliant companies in the plantation industry. Their research discovered that more than half of the sample (i.e., companies that implemented Shariah-compliance measures) responded with good results in terms of performance and companies' position. Therefore, Shariahcompliance measures can be used as basis for a thorough investigation of the development of Shariah-compliant companies in the plantation industry's performance.

A study on Shariah property investment in Asia reveals that more than $95 \%$ of the respondents agreed that choosing Shariah-compliant companies is an essential requirement for "halal" investments and investment structures (Mohd-Sanusi, Ismail, Hudayati, \& Harjito, 2015). Compliance to Shariah principles is fundamental, and investors decide to invest only when compliance is ensured. The current potential of Islamic investments in Asia is very high. These results can drive the interest of the Muslim community, which is now more aware of the issues on which type of investment to choose. Furthermore, $78 \%$ of the respondents felt that Southeast Asia has the highest potential in attracting Shariah-compliant real estate investment (Kasim \& Sanusi, 2013).

Measuring the relationship among religion, ethical values, and earnings management using abnormal accruals is a common method to determine accounting quality (Dechow et al., 1995). The results show high abnormal accruals, which indicate that a firm may be manipulating earnings. Shariah-compliant companies also have significantly lower levels of abnormal accrual than non-Shariah companies. Therefore, a negative relationship exists between earnings management and religious business norms, which include Shariah accountability. Such ethics when company policies introduce religious ethics may be important to determine whether a company practices earnings management.

\section{Hypothesis Development}

This study examines discretionary-accrualtype earnings management by focusing on the relationship among risk of financial distress, leverage, and free cash flow, with the possibility of earnings management.

Previous research has proved that internal and external factors can affect the role of managerial ownership in reducing agency conflict (Aini et al., 2006; Alves, 2012; Chen $\&$ Liu, 2010). The results in Warfield, Wild, and Wild (1995) suggest that the role of managerial ownership in reducing earnings management is not effective in regulated firms. Therefore, monitoring regulators may have substituted the role of managerial ownership to reduce agency conflicts.

Bushman, Chen, Engel, and Smith (2004) suggested that the demand for more systematic corporate governance is higher in large firms than in small firms because of the high degree of information asymmetry between managers and shareholders in large firms. Large firms are naturally more complex and have a more dispersed ownership structure than small firms. The high degree of information asymmetry in 
large firms requires corporate governance and other monitoring mechanisms to be better than those in small firms (Singh \& Davidson, 2003). Therefore, the hypothesis of the present study is consistent with Warfield et al. (1995); Ang, Cole, and Lin (2000); Sulong, Gardner, Hussin, Mohd Sanusi, and McGowan (2013); Yeo, Tan, Ho, and Chen (2002).

H1: A significant relationship exists between firm size and earnings management of Shariah-compliant companies.

The financial leverage of firms is measured as the ratio of debt to assets and is included as a proxy for risk, as managers more likely exercise their accounting discretion granted by generally accepted accounting principles (GAAP) when they are closer to default on debt covenants (Press $\&$ Weintrop, 1990). Trueman and Titman (1988, p. 128) argued that "managing earnings enables managers to reduce the estimates of various claimants of the firm about the volatility of its earnings process and to lower their assessment of the probability of bankruptcy." Therefore, managing earnings provides an opportunity to borrow at lower interest rates and decreases capital cost as proposed by Atik (2009); Hadi and Kamaluddin (2015); Kamaluddin, Rahman, Mara, and Alam (2007); Selahudin, Zakaria, Sanusi, and Budsaratragoon (2014) .The debt hypothesis is stated as follows:

H2: A significant relationship exists between leverage and earnings management of Shariah-compliant companies.

In previous literature, different terms have been used for accounting accruals, which refer to the difference between earnings and cash flows from operating activities. Healy and Wahlen (1999) used total accruals to measure earnings management. Conversely, subsequent studies attempted to separate total accruals into discretionary and non-discretionary accruals. Discretionary accruals are extensively used to demonstrate that managers transfer their accounting earnings from one period to another.
That is, managers exercise their discretion over an opportunity set of accrual choices within GAAP (e.g., choosing the depreciation method of fixed assets) (Healy \& Wahlen, 1999). Moreover, total accruals include non-discretionary accruals that reflect un-manipulated accounting accrual items because these accruals are out of the managers' control. Therefore, the following hypothesis is consistent with the previous literature on earnings management, such as Cohen and Zarowin (2010); Ghani and Said (2010); Jones (1991); Reyna (2012).

H3: A significant relationship exists between free cash flow and earnings management of Shariah-compliant companies.

\section{Methodology}

\section{Sample Selection}

A total of 839 companies were approved by the Securities Commission as Shariah-compliant as of November 2014. An estimated 774 companies were identified for the analysis based on the data available in Thomson Datastream. Secondary data, which consist of the financial statement component, were collected from Datastream. Data on the Shariah status of companies listed in Bursa Malaysia were gathered from the Securities Commission's latest listing of Shariah-approved companies. The list can be found on the website of the Securities Commission.

\section{Measurement of Dependent Variable}

Various models have been used to estimate earnings management, though discretionary accruals are the most widely used as substitute (Dechow et al., 1995). Dechow et al. (1995) found that the best performing model is the modified version of the (Jones, 1991) model. Nevertheless, the present study followed the model suggested by Khotari et al. (2005), who argued that an accurate estimation of discretionary accruals could not be achieved using the existing models. 
Khotari et al. (2005) suggested that performancematched discretionary accruals measurement could enhance the reliability of inferences in earnings management. Therefore, the present study selected performance that matches discretionary accruals because the Jones and modified Jones models are not suitable when applied to a random sample. The performancematched discretionary accruals model is an alternative to measure discretionary accruals based on a stratified random and representative sample. Compared with the modified Jones model, which was reintroduced in 1995, the performance-matched discretionary accruals model is one of the new models proposed in 2005 by estimating discretionary accruals.

The current study estimates the amount of earnings management by using total accruals (TACC), which is an amount of the nondiscretionary component of accruals and discretionary accruals. The amount is generated through normal business activities and is important for managers to evaluate outcomes. Moreover, TACC refers to the estimated discretionary accruals used to obtain the amount involved in the study of earnings management. The accrual amount is categorized into nondiscretionary and discretionary accruals. Therefore, the regression model consists of non-discretionary accruals, which are expected accruals explained by selected variables, and discretionary accruals, which are unexpected accruals that are not explained by the variables selected according to the objectives of the study.

TACC is calculated as follows:

TACCit $=$ DACCit + NDACCit,

where

TACCit $=$ total accruals of firm $\mathrm{i}$ in year $\mathrm{t}$, DACCit $=$ discretionary accruals of firm $\mathrm{i}$ in year $t$, and

NDACCit $=$ non-discretionary accruals of firm $\mathrm{i}$ in year $\mathrm{t}$.
The heteroskedasticity of the regression is reduced by deflating each component in the total accruals by lagged total assets (Bukit \& Iskandar, 2009; Chung, Firth, \& Kim, 2005). Therefore, TACC is calculated as follows:

TACC $=(\Delta$ Cash $-\Delta$ Current Assets $)-(\Delta$ in Current Liabilities $+\Delta$ Current portion of long term debt) - Depreciation and Amortization Lagged total assets

where

$\Delta=$ change from year $\mathrm{t}-1$ to year $\mathrm{t}$, and Lagged total assets $=$ total assets of firm $i$ at the end of year $\mathrm{t}-1$.

This study follows the Kothari Model, where ROAit or ROAit-1 stands for the current and the previous year's ROA, respectively, to control the firm's performance and categorize total accruals into discretionary and non-discretionary accruals. The model includes ROA to compare the effectiveness of performance matching and the regression-based approach (Kothari et al., 2005).

The discretionary accruals regression model captures the components of total accruals and non-discretionary accruals as follows:

TACCit $=\alpha_{0}+\alpha_{1}(1 /$ TAit -1$)+\alpha_{2}(\Delta$ SALESit / TAit-1) $+\alpha_{3}$ (PPEit / TAit-1) $+\alpha_{4}$ ROAit (or it-1) + eit,

where

TACCit $=$ total accruals of firm $\mathrm{i}$ in year $\mathrm{t}$, TAit $-1=$ total assets of firm $i$ at the end of year $\mathrm{t}-1$,

$\triangle$ SALES $=$ sales change in net of the change of account receivables of firm $i$ between years $\mathrm{t}$ and $\mathrm{t}-1$,

PPE $=$ the level of gross property, plant, and 
equipment of firm $i$ in year $t$,

ROAit (or it -1 ) $=$ ROA of firm $i$ at the end of year $t$ (ROA of firm $i$ at the end of year $t-1$ ), and $\varepsilon=$ regression residual.

Therefore, non-discretionary accruals are defined by the fitted value obtained from the regression model, while discretionary accruals are defined by the residual value obtained from the regression model. Fitted value refers to the difference between total and non-discretionary accruals and is used as the dependent variable in this study.

\section{Measurement of Independent Variables}

The Z-score model is chosen as a substitute for the risk of financial distress (Oluwo, 2007), working capital over total assets, retained earnings over total assets, earnings before interest and taxes over total assets, market value of equity over book value of total debt, and sales over total assets. The formula for the $\mathrm{Z}$-score is given by

$Z=1.2 x(1)+1.4 x(2)+3.3 \times(3)+0.6 x(4)+$ $1.0 x(5)$,

where

$\mathrm{Z}=$ overall classification index,

$\mathrm{x}(1)=$ working capital over total assets,

$x(2)=$ retained earnings over total assets,

$x(3)=$ earnings before interest and taxes over total assets,

$\mathrm{x}(4)=$ market value of equity over book value of total debt, and

$x(5)=$ sales over total assets.

Owing to discrimination, Altman's model is divided into three zones to show that a company encounters financial hardship. The zone located below 1.81 is the distress zone, that between 1.81 and 2.99 is the grey zone, and that above 2.99 is the safe zone.
The best discriminatory zone is located above 2.88 , which shows that the company has a healthy financial situation. Companies found in the discrimination zone of 1.81 and below are considered to be undergoing financial hardship and bankruptcy. The discrimination zone between 1.81 and 2.99 is considered the zone of ignorance. Companies found in this zone may incorrectly classify their financial information. The cut-off of the account point of 2.675 determines whether a company has financial problems. Anything below 2.675 is considered a business failure. The above model is used as a tool to learn and predict the financial health of a company (Drus, Hamzah \& Yusoff, 2013; Oluwo, 2007).

The following equation is used to measure debt-to-equity ratio: debt/total equity and debtto-assets ratio $=$ total debt/assets. Leverage ratios indicate the level of long-term debt with long-term measures in a company's balance sheet. A highly available leverage shows that a company's management has the potential to violate the loan agreement, resulting in its inability to obtain additional capital through loans.

Previous studies have suggested that relative cash flow has a negative relationship with discretionary accounting accruals (Becker, DeFond, Jiambalvo, \& Subramanyam, 1998). A significantly high cash flow indicates high profits and encourages companies to accept low-income discretionary accounting accruals to smoothen income. Indicator changes are included as relative cash flow to control the potential effect on cash flow. Free cash flow is measured by the cash flow for the year divided by the lagged total assets (year $\mathrm{t}-1$ ). This approach is similar to that of Chung et al. (2005). Therefore, the present study expects a negative sign on the coefficient of the other and a tendency flow with relatively high cash to practice window dressing on the account of a particular income. 


\section{Measurement of Control Variables}

This study used three control variables: ROA, size, and liquidity. ROA is used to measure the profitability aspect ratio. ROA was calculated as revenue/total assets, and net profit for revenue was calculated as net profit/revenue. Summers and Sweeney (1998) supported the current study. A company's management is expected to maintain or increase the level of past profits, regardless of the actual extent of such profits. If the actual performance of the company does not meet the investors' expectations, then the managers will have the potential to manipulate information in the financial reports.

The present study measured the size of the client $\log$ of total assets to control the influence of the client size on the quality of accruals (i.e., earnings management). This step was followed by a measurement advocated by Choi, Kim, Kim, and Zang (2010); Dechow and Dichev (2002). Earnings management in a company explains that firm size has a significant effect on discretionary accruals.

The ratios used are as follows: liquidity = working capital/total assets, current ratio $=$ current assets/current liabilities, and inventory to sales $=$ total inventory/revenue.

These ratios measure the capacity of a business to meet its financial obligations in the short term. A financial analysis report noted that the current ratio is one of the most important ratios that measure a company's liquidity (Kastantin, 2005). Companies with a low level of liquidity can encourage its managers to engage in earnings management.

\section{Results and Discussion}

\section{Descriptive Analysis}

Descriptive analysis enabled the current study to explore and improve our understanding of the data collected and used. This section presents a summary of the descriptive statistics. Table 1 shows the summary of the statistics for the full sample that consists of earnings management.

\begin{tabular}{|c|c|c|c|c|c|c|}
\hline & 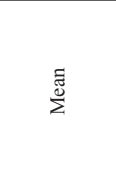 & 声 & 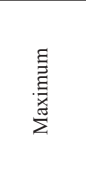 & 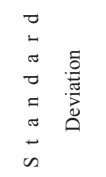 & 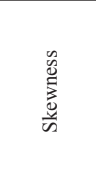 & $\begin{array}{l}\frac{n}{02} \\
\frac{2}{0} \\
\frac{1}{2}\end{array}$ \\
\hline DA & -1.0168 & -4.66 & 0.33 & 0.75106 & -0.779 & 1.552 \\
\hline Abs & 1.0141 & 0.00 & 4.45 & 0.72685 & 0.613 & 0.819 \\
\hline ROA & 0.0299 & 0.43 & 0.30 & 0.08163 & -0.871 & 3.067 \\
\hline LogAsset & 5.3733 & 3.76 & 7.02 & 0.57693 & 0.121 & -0.193 \\
\hline LQ & 0.2186 & -1.05 & 0.92 & 0.23791 & -0.328 & 1.501 \\
\hline ZSCORE & 2.8021 & -0.29 & 12.44 & 1.95765 & 1.313 & 2.408 \\
\hline LEV & 0.3749 & 0.00 & 1.46 & 0.21248 & 0.556 & 0.611 \\
\hline FCF & 0.0589 & -0.49 & 0.62 & 0.09505 & 0.058 & 2.928 \\
\hline
\end{tabular}

Note: DA represents discretionary accruals, Abs represents absolute discretionary accruals, ROA represents profitability, LogAsset represents firm size, LQ represents liquidity, ZSCORE represents risk of financial distress, LEV represents leverage, and FCF represents free cash flow.

Most of the variables have positive skewness and kurtosis. Therefore, most data are distributed at positive values and cluster at the center. The data are close to the normal distribution and suggest that the assumption of normality is not violated.

\section{Pearson's Correlation Product Moment}

Table 2 shows the relationship between the dependent and independent variables. The absolute discretionary accruals (DA) have a positive correlation with the risk of financial distress of the firm, $r=0.139, p<0.01$. This finding shows that the high risk of financial distress leading to the bankruptcy of a company offers a high probability of engaging in earnings management. 
DA correlates with leverage $(\mathrm{r}=-0.146, \mathrm{p}<$ $0.01)$ as well. This finding indicates the high earnings management of high leverage in firms. Managers have a strong intention to engage in earnings management with high leverage to avoid debt covenant violation. Furthermore, the absolute discretionary accruals also correlate significantly with free cash flow $(r=0.192$, $p$ $<0.01)$. This correlation shows that high free cash flow corresponds to the high earnings management practice of a company. Therefore, managers have the intention to invest in nonvalue investment and, ultimately, misuse funds for personal gain.

The risk of financial distress has a negative correlation with firm leverage $(r=-0.631, p$ $<0.01)$. This finding reveals that a high level of risk of financial distress results in the low leverage of a firm. The risk of financial distress also has a positive correlation with free cash flow $(r=-0.270, p<0.01)$. This result shows that financial distress with a high level of risk results in low free cash flow. Therefore, the results suggest no multicollinearity problem in this model, and no independent variable is rejected from this study.

Table 2: Pearson's correlation between independent and dependent variables

\begin{tabular}{|c|c|c|c|c|c|c|c|}
\hline 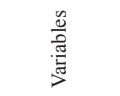 & $\stackrel{n}{<}$ & $\underset{\Omega}{\overleftarrow{q}}$ & 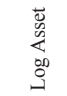 & $\stackrel{0}{9}$ & $\begin{array}{l}\text { ज्ञ } \\
\text { ర్ } \\
\text { N }\end{array}$ & 盆 & 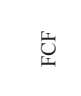 \\
\hline Abs & 1 & $.179^{* *}$ & $0.129^{* *}$ & -0.031 & $0.139^{* * *}$ & $0.146^{* *}$ & $0.192^{* *}$ \\
\hline ROA & & 1 & $0.222^{* *}$ & $0.289^{* *}$ & $0.390^{* *}$ & $-0.249^{* *}$ & $0.395^{* *}$ \\
\hline LogAsset & & & 1 & $-0.233^{* *}$ & $-0.211^{* *}$ & $0.206^{* *}$ & $0.073^{* *}$ \\
\hline LQ & & & & 1 & $0.673^{\circ *}$ & $-0.601^{* *}$ & $0.159^{* *}$ \\
\hline ZSCORE & & & & & 1 & $-0.631^{* *}$ & $0.270^{* *}$ \\
\hline LEV & & & & & & 1 & $-0.174^{*+}$ \\
\hline FCF & & & & & & & 1 \\
\hline
\end{tabular}

"Correlation is significant at the 0.05 level (2-tailed).

${ }^{* *}$ Correlation is significant at the 0.01 level (2-tailed).

\section{Regression Analysis}

Table 3 presents the regression results for the pooled year for the first, second, and third hypotheses. Table 4 follows with an additional analysis divided into years.
Table 3 presents the regression results for the pooled data to test the hypotheses.

Table 3: Results of the regression analysis on earnings management from 2012 to 2014

\begin{tabular}{|c|c|c|c|c|c|}
\hline & \multicolumn{2}{|c|}{$\begin{array}{c}\text { Unstandardized } \\
\text { Coefficients }\end{array}$} & \multirow{2}{*}{$\begin{array}{c}\text { Standardized } \\
\text { Coefficients } \\
\text { Beta }\end{array}$} & \multirow[t]{2}{*}{$\mathrm{t}$} & \multirow[t]{2}{*}{ Significant } \\
\hline & Beta & $\begin{array}{l}\text { Std. } \\
\text { Error }\end{array}$ & & & \\
\hline (Constant) & -0.439 & 0.163 & & -2.696 & 0.07 \\
\hline ROA & 0.673 & 0.217 & 0.076 & $3.105^{* *}$ & 0.002 \\
\hline LogAsset & 0.111 & 0.028 & 0.088 & $3.983^{* * * *}$ & 0.000 \\
\hline LQ & -0.302 & 0.088 & -0.099 & $-3.433^{* * *}$ & 0.001 \\
\hline ZSCORE & 0.141 & 0.011 & 0.381 & $12.311^{* * * *}$ & 0.000 \\
\hline LEV & 1.198 & 0.093 & 0.350 & $12.875^{* * *}$ & 0.000 \\
\hline FCF & 0.985 & 0.169 & 0.129 & $5.842^{* * * *}$ & 0.000 \\
\hline $\mathrm{R}^{2}$ & 0.157 & & & & \\
\hline Adjusted & 0.154 & & & & \\
\hline \multicolumn{6}{|l|}{$\mathrm{R}^{2}$} \\
\hline F-Statistic & & $65.081^{* * * *}$ & & & \\
\hline
\end{tabular}

**** Significant at the 0.001 level (Sig 2-tailed).

${ }^{* *}$ Significant at the 0.01 (Sig 2-tailed).

"Significant at the 0.05 level (Sig 2-tailed).

The result shows that all variables influence earnings management practices in their companies, and a significant relationship exists between risk of financial distress and earnings management. Barsky, Catanach Jr, and RhoadesCatanach (2003); Spathis (2002) obtained the same results in their studies. Therefore, Hypothesis 1 is supported. A company may practice earnings management because of financial distress, which can be discovered if it causes managers from Shariah-compliant companies to practice earnings management. A relationship between leverage and earnings management can be observed. The relationship between leverage and discretionary accruals is expected to be positive. Therefore, Hypothesis 2 is supported. Managers may be motivated to understate liabilities or overstate assets to ensure that debt covenants are achieved if a company is unable to obtain extra capital through a loan. That is, a company with a high total debt is highly likely to practice earnings management. 
Table 3 shows the significant relationship between free cash flow and earnings management. A high level of free cash flow in a company increases the probability of earnings management practice. A manager may be motivated to engage in earnings management to ensure that the free cash flow is balanced with the total assets. Therefore, the result supports Hypothesis 3. This finding is consistent with the studies by Bukit and Iskandar (2009); Chung et al. (2005); Gul (2001).

Regression analysis was performed to explain the relationship between the independent and control variables in the absolute discretionary accruals as the dependent variables by separating the years 2012, 2013, and 2014 . The results of multiple regressions in different years are presented in Table 4.

The result reveals that the 2013 model has a better R-square than the 2012 and 2014 models. Therefore, this model can enhance the explanation of the dependent variable of earnings management using the independent variable and show that the interaction after the original independent variable is controlled.

The 2013 model explains $24.9 \%$ of the variance of discretionary accrual, which is substituted for the earnings management. The variance of discretionary accrual is $18.7 \%$ in 2012 and $14.1 \%$ in 2014 . The F value shows that 26.504 , 38.470 , and 19.055 are the significant values ( $p$ $<0.001$ ) for 2012, 2013, and 2014, respectively.

A significant relationship between financial distress and discretionary accruals is predicted in Hypothesis 1 (H1). The result shows a significant relationship between financial distress and discretionary accrual for three years. Therefore, H1 is supported.

Table 4: Results of the regression analysis on earnings management for 2012 to 2014

\begin{tabular}{|c|c|c|c|c|c|c|}
\hline & \multicolumn{2}{|c|}{2012} & \multicolumn{2}{|c|}{2013} & \multicolumn{2}{|c|}{2014} \\
\hline & $\begin{array}{l}\text { Standardized } \\
\text { Coefficients }\end{array}$ & $\mathrm{t}$ & $\begin{array}{c}\text { Standardized } \\
\text { Coefficients }\end{array}$ & $\mathrm{T}$ & $\begin{array}{c}\text { Standardized } \\
\text { Coefficients }\end{array}$ & $\mathrm{t}$ \\
\hline (Constant) & & -6.225 & & 0.5 & & 1.515 \\
\hline ROA & -0.032 & -0.789 & 0.074 & $1.794^{*}$ & 0.107 & $2.511^{* *}$ \\
\hline LogAsset & .0270 & $7.081^{* * *}$ & -0.031 & -0.860 & 0.003 & 0.069 \\
\hline LQ & -0.128 & $-2.538^{* *}$ & -0.127 & $-2.641^{* *}$ & -0.054 & -1.095 \\
\hline ZSCORE & 0.366 & $6.890^{* * * *}$ & 0.500 & $9.263^{* * * *}$ & 0.284 & $5.439^{* * * *}$ \\
\hline LEV & 0.197 & $4.452^{* * *}$ & 0.495 & $10.726^{* * *}$ & 0.405 & $8.204^{* * * *}$ \\
\hline FCF & 0.185 & $4.815^{* * *}$ & 0.202 & $5.491^{* * * *}$ & 0.154 & $4.015^{* * * *}$ \\
\hline $\mathrm{R}^{2}$ & 0.187 & & 0.249 & & 0.141 & \\
\hline Adjusted $\mathrm{R}^{2}$ & 0.180 & & 0.242 & & 0.133 & \\
\hline F-Statistic & $26.504^{* * * *}$ & & $38.470^{\text {**** }}$ & & $19.055^{* * *}$ & \\
\hline
\end{tabular}

${ }^{* * *}$ Significant at the 0.001 level (Sig 2-tailed).

**Significant at the 0.01 (Sig 2-tailed)

*Significant at 0.05 level (Sig 2-tailed). 
Hypothesis 2 (H2) expects a significant relationship between leverage and discretionary accruals. The results for 2012, 2013, and 2014 support $\mathrm{H} 2$, and therefore $\mathrm{H} 2$ is supported. Table 4.5(b) shows a significant positive relationship with absolute discretionary accruals $(\beta=0.197$, $\mathrm{p}<0.05),(\beta=0.495, \mathrm{p}<0.001)$, and $(\beta=$ $0.405, \mathrm{p}<0.001)$ for 2012, 2013, and 2014, respectively.

Hypothesis 3 (H3) predicts a significant relationship between free cash flow and discretionary accruals. The results reveal that H3 is supported. For 2014, Table 4.5(b) shows a significant positive relationship between log free cash flow and absolute discretionary accruals $(\beta=0.185, \mathrm{p}<0.05)$. For 2013, Table 4.5(b) reveals that $\log$ free cash flow has a significant positive relationship with absolute discretionary accruals $(\beta=0.202, p<0.001)$. For 2014, log free cash flow has a significant relationship with discretionary accruals $(\beta=0.154, \mathrm{p}<0.001)$.

\section{Conclusions}

This study examined the characteristics of financial distress and leverage and aimed to discover whether these variables have a significant relationship with the probability of managers practicing earnings management. It further examined the financial distress factors in relation to Shariah-compliant companies in Malaysia. This study could contribute to existing studies with similar themes. This empirical research was conducted using a sample of Malaysian firms from all industries of Shariahcompliant companies in Bursa Malaysia from 2012 to 2014 . The regression analysis used to test all the hypotheses was applied only to the final sample of 774 firms at the end of the sample period from 2012 to 2014. This study used the performance-matched discretionary accruals approach (Kothari et al., 2005), and the dependent variables served as substitutes for earnings management. The three hypotheses were tested using a regression model. All hypotheses were accepted using pooled data from 2012 to 2014. Thus, managers of firms with financial distress, high leverage, and free cash flow could manage their companies' earnings.

The results should interest stakeholders, shareholders, and regulatory bodies (i.e., Shariah Advisory Council and Securities Commission) that oversee the accountability of corporate financial reporting to reduce earnings management in Shariah-compliant companies. The findings can also assist relevant authorities (i.e., Shariah Advisory Council and Security Commission and other agencies) in Malaysia in overcoming or reducing the problems related to earnings management. The findings of this study indicate that managing earnings enables managers to reduce certain financial figures of the firm that affect the volatility of its earnings process and lower the risk posed by assessment of the uncertainties among Shariah-compliant companies.

This study has a number of limitations, and thus the evaluation of the results should be construed in light of these limitations. First, this study used a sample from a three-year period, which is considered moderate compared with that used in other studies. Second, the study focused on Shariah-listed companies from all types of industries in Malaysia. However, Haniffa, Abdul Rahman, and Haneem Mohamed Ali (2006) included all industries except for financial institutions. Focusing on all sectors for more than three years would result in a larger sample and more significant results.

This study suggests that future research should consider extending the sample size to obtain better results so that more significant relationships could be discovered. Moreover, using a large sample is strongly suggested. The timeframe should be extended to five or ten years compared with the three years used in this study. Extending the timeframe may produce more significant results. The latest studies or new models can also be used to detect earnings management (i.e., discretionary accruals) and compare which model may offer the best possible solutions to detect earnings 
management. Finally, this study can be extended to include detailed information for other relevant factors, such as asset utilization, audit fees, properties, plants, and equipment.

\section{Acknowledgement}

The authors would like to express their gratitude to the Accounting Research Institute, Universiti Teknologi MARA and the Ministry of Education for funding and facilitating this research project.

\section{References}

Abdul Rahman, A., Azlan Yahya, M., \& Herry Mohd Nasir, M. (2010). Islamic norms for stock screening: A comparison between the Kuala Lumpur stock exchange Islamic index and the dow jones Islamic market index. International Journal of Islamic and Middle Eastern Finance and Management, 3(3), 228-240.

Aini, A., Takiah, M., Hamid, P., \& Jenny, T. (2006). Earnings management in Malaysia: A study on effects of accounting choices.

Al-Shammari, B. (2013). An investigation of voluntary disclosure by Kuwaiti Shariahcompliant companies. Journal of Economic and Administrative Sciences, 29(1), 21-41.

Alam, M. M., Hassan, S., \& Said, J. (2015). Performance of Islamic microcredit in perspective of Maqasid Al-Shariah: A case study on Amanah Ikhtiar Malaysia. Humanomics, 31(4), 374-384.

Alves, S. (2012). Ownership structure and earnings management: Evidence from Portugal. Australasian Accounting, Business and Finance Journal, 6(1), 57-74.

Ang, J. S., Cole, R. A., \& Lin, J. W. (2000). Agency costs and ownership structure. The journal of finance, 55(1), 81-106.

Atik, A. (2009). Detecting income-smoothing behaviors of Turkish listed companies through empirical tests using discretionary accounting changes. Critical perspectives on accounting, 20(5), 591-613.

Bakar, M.A.A.A., \&Ali, N. (2014). Performance Measurement Analysis: Shariah-compliant vs. Non Shariah-compliant Securities. Malaysian Accounting Reveiw (MAR), 13(1), 75-108.

Barsky, N. P., Catanach Jr, A. H., \& RhoadesCatanach, S. C. (2003). Analyst Tools for Detecting Financial Reporting Fraud. Com. Lending Rev., 18, 31.

Bukit, R. B., \& Iskandar, T. M. (2009). Surplus free cash flow, earnings management and audit committee. International Journal of Economics and Management, 3(1), 204-223.

Bursa Malaysia Securities Berhad. (2009). Main market listing requirements. Kuala Lumpur: Bursa Malaysia Securities Berhad. Available at: http://www.bursamalaysia.com/website/bm/ regulation/rules/listing_ requirements/main market.html.

Bushman, R., Chen, Q., Engel, E., \& Smith, A. (2004). Financial accounting information, organizational complexity and corporate governance systems. Journal of Accounting and Economics, 37(2), 167-201.

Chapra, M. U., \& Chapra, M. U. (1992). Islam and the economic challenge: Islamic foundation Leicester.

Chen, K., \& Liu, J.-L. (2010). Earnings Management, CEO Domination, and Growth Opportunities: Evidence from Taiwan. International Journal of Public Information Systems, 6(1).

Choi, J.-H., Kim, C., Kim, J.-B., \& Zang, Y. (2010). Audit office size, audit quality, and audit pricing. Auditing: A Journal of Practice \& Theory, 29(1), 73-97.

Chung, R., Firth, M., \& Kim, J.-B. (2005). 
Earnings management, surplus free cash flow, and external monitoring. Journal of Business Research, 58(6), 766-776.

Cohen, D. A., \& Zarowin, P. (2010). Accrualbased and real earnings management activities around seasoned equity offerings. Journal of Accounting and Economics, 50(1), 2-19.

Dali Nuradli Ridzwan Shah Bin, M., Hamdi Hakeim, M., \& Hamid Suhaila, A. (2008). Performance of Shariah compliance companies in the plantation industry. International Journal of Islamic and Middle Eastern Finance and Management, 1(2), 166-178.

Darus, F., Amran, A., Nejati, M., \& Yusoff, H. (2014). Corporate social responsibility towards the community: evidence from Islamic financial institutions in Malaysia. International Journal of Green Economics, 8(3-4), 273-287.

Darus, F., Hamzah, E. A. C. K., \& Yusoff, H. (2013). CSR web reporting: The influence of ownership structure and mimetic isomorphism. Procedia Economics and Finance, 7, 236-242.

Dechow, P. M., \& Dichev, I. D. (2002). The quality of accruals and earnings: The role of accrual estimation errors. The accounting review, 77(s-1), 35-59.

Dechow, P. M., Sloan, R. G., \& Sweeney, A. P. (1995). Detecting earnings management. Accounting review, 193-225.

Derigs, U., \& Marzban, S. (2008). Review and analysis of current Shariah-compliant equity screening practices. International Journal of Islamic and Middle Eastern Finance and Management, 1(4), 285-303.

Durant, W. (1950). The Story of Civilization...: The age of faith (Vol. 4): Simon and Schuster.

Elgari, M. A. (1993). Towards an Islamic stock market. Islamic Economic Studies, 1(1), 1-20.
Falaika. (2002). Islamic investment criteria. Available at: http://www.failaka.com/ Failaka\%20 Research.html.

Farooq, O., AbdelBari, A., \& Haniffa, R. (2015). Earnings management behaviour of shariahcompliant firms and non-shariah-compliant firms: evidence from the MENA region. Journal of Islamic Accounting and Business Research, 6(2).

Ghani, E., \& Said, J. (2010). Digital Reporting Practices Among Malaysian Local Authorities. Electronic Journal of e-Government, 8(1).

Gul, F. A. (2001). Free cash flow, debtmonitoring and managers' LIFO/FIFO policy choice. Journal of Corporate Finance, 7(4), 475-492.

Hadi, N. A., \& Kamaluddin, A. (2015). Social collateral, repayment rates, and the creation of capital among the clients of microfinance. Procedia Economics and Finance, 31, 823-828.

Haniffa, R., Abdul Rahman, R., \& Haneem Mohamed Ali, F. (2006). Board, audit committee, culture and earnings management: Malaysian evidence. Managerial Auditing Journal, 21(7), 783-804.

Hassan, N., Yusoff, H., \& Yatim, N. (2012). Disclosing social responsibility information via the Internet: A study on companies in Malaysia. International Journal of Arts and Commerce, 1(5), 83-96.

Healy, P. M. (1985). The effect of bonus schemes on accounting decisions. Journal of Accounting and Economics, 7(1), 85-107.

Healy, P. M., \& Wahlen, J. M. (1999). A review of the earnings management literature and its implications for standard setting. Accounting horizons, 13(4), 365-383.

IOSCO, I. C. M. T. C. O. S. (2004). Islamic Capital Market Fact Finding Report. 
Jones, T. M. (1991). Ethical decision making by individuals in organizations: An issuecontingent model. Academy of management review, 16(2), 366-395.

Kamaluddin, A., Rahman, R., Mara, U., \& Alam, S. (2007). The moderating effect of organisation culture on intellectual capital and organisational effectiveness relationships. Paper presented at the International Conference on Intellectual Capital, Knowledge Management \& Organizational Learning.

Kasim, N., \& Sanusi, Z. M. (2013). Emerging issues for auditing in Islamic Financial Institutions: Empirical evidence from Malaysia. IOSR Journal of Business and Management, 8(5), 10-17.

Kastantin, J. T. (2005). Beyond earnings management: Using ratios to predict Enron's collapse. Managerial Finance, 31(9), 35-51.

Kazemian, S., \& Sanusi, Z. M. (2015). Earnings Management and Ownership Structure. Procedia Economics and Finance, 31, 618-624.

Kothari, S. P., Leone, A. J., \& Wasley, C. E. (2005). Performance matched discretionary accrual measures. Journal of Accounting and Economics, 39(1), 163-197.

Leuz, C., Nanda, D., \& Wysocki, P. D. (2003). Earnings management and investor protection: an international comparison. Journal of financial economics, 69(3), 505-527.

MIA, M. I. o. A. (2002). The Auditors' Responsibility to Consider Fraud and Error in An Audit of Financial Stataments.

Mohamed Adil, M. A., \& Mohd-Sanusi, Z. (2013). Financial Management Practices of Mosques in Malaysia. Global Journal AlThaqafah, 3(1), 23-29.

Mohd-Sanusi, Z., Ismail, R., Hudayati, A., $\&$ Harjito, D. (2015). Screening Process of
Shariah-Compliant Companies: The Relevance of Financial Risk Management. International Journal of Economics \& Management, 9(1), 177-195.

Nadzri, A., \& Aida, F. (2009). Roles and impacts of accounting and auditing organization for Islamic financial institutions (AAOIFI) in dealing with the accounting and disclosure of Zakah and interest (Riba). Auckland University of Technology.

Oluwo, M. (2007). Strategic Use of Financial Ratio to Prevent Bankruptcy: A Study of Opportunity for Business Enterprises: ProQuest.

Press, E. G., \& Weintrop, J. B. (1990). Accounting-based constraints in public and private debt agreements: Their association with leverage and impact on accounting choice. Journal of Accounting and Economics, 12(1), 65-95.

Reyna, J. M. S. M. (2012). An Empirical Examination of Ownership Structure, Earnings Management and Growth Opportunities in Mexican Market. International Journal of Business and Social Research, 2(7), 103-123.

Said, J. (2010). The Mediating Effects of Organizational Learning Orientation on the Relationship between Strategic Management Accounting Information Use and Organizational Performance. Asia-Pacific Management Accounting Journal, 5(2), 11-29.

Schelling, T. C. (1968). Game theory and the study of ethical systems. Journal of Conflict Resolution, 34-44.

Securities Commission. (2011). List of Shariahcompliant securities by the Shariah advisory council of the securities commission Malaysia. Kuala Lumpur: Securities Commission.

Selahudin, N. F., Zakaria, N. B., Sanusi, Z. M., \& Budsaratragoon, P. (2014). Monitoring financial risk ratios and earnings management: Evidence 
from Malaysia and Thailand. Procedia-Social and Behavioral Sciences, 145, 51-60.

Shafiai, M. H. M., \& Moi, M. R. (2015). Fitting Islamic financial contracts in developing agricultural land. Global Journal Al-Thaqafah, 5(1), 43-49.

Singh, M., \& Davidson, W. N. (2003). Agency costs, ownership structure and corporate governance mechanisms. Journal of Banking \& Finance, 27(5), 793-816.

Spathis, C. T. (2002). Detecting false financial statements using published data: some evidence from Greece. Managerial Auditing Journal, 17(4), 179-191.

Sulaiman, M. (2003). The influence of riba and zakat on Islamic accounting. Indonesian Management and Accounting Review, 2(2), 149-167.

Sulong, Z., Gardner, J. C., Hussin, A. H., Mohd Sanusi, Z., \& McGowan, C. B. (2013). Managerial Ownership, Leverage and Audit Quality Impact on Firm Performance: Evidence from the Malaysian ACE Market. Accounting \& Taxation, 5(1), 59-70.

Sun, L., \& Rath, S. (2008). Fundamental determinants, opportunistic behavior and signaling mechanism: an integration of earnings management perspectives. International Review of Business Research Papers, 4(4), 406-420.

Trueman, B., \& Titman, S. (1988). An explanation for accounting income smoothing. Journal of Accounting Research, 127-139.

Wan Ismail, W. A., Kamarudin, K. A., \& Sarman, S. R. (2015). The quality of earnings in Shariah-compliant companies: evidence from Malaysia. Journal of Islamic Accounting and Business Research, 6(1), 19-41.

Warfield, T. D., Wild, J. J., \& Wild, K. L. (1995). Managerial ownership, accounting choices, and informativeness of earnings. Journal of Accounting and Economics, 20(1), 61-91.

Yeo, G. H., Tan, P., Ho, K. W., \& Chen, S. S. (2002). Corporate ownership structure and the informativeness of earnings. Journal of Business Finance \& Accounting, 29(7-8), 1023-1046.

Yousef, D. A. (2001). Islamic work ethic-A moderator between organizational commitment and job satisfaction in a cross-cultural context. Personnel Review, 30(2), 152-169. 